\title{
EFFECTIVENESS OF DIFFERENT FORMS OF HEATING
}

\author{
BY \\ H. M. WHYTE and S. R. READER \\ From the Nuffield Department of Clinical Medicine, \\ Radcliffe Infirmary, Oxford
}

It is generally stated that diathermy and penetrating short-wave infra-red radiation are more effective for heating deep subcutaneous tissues than are the non-penetrating rays of long-wave infra-red or the heat derived from direct contact, but there are few experimental studies on the extent of the difference involved. We report here some observations on the temperature changes produced in the lumbar region by these different methods of heating.

\section{Methods}

Tests were made in the lumbar area of one subject on different days. The area was made flat by having the subject prone with pillows packed under the abdomen, and temperatures were measured at the centre point of the area, $2.5 \mathrm{~cm}$. to the right of the second lumbar vertebral spine. Skin temperature was recorded with two copperconstantan wire thermocouples (Whyte, 1951), and subcutaneous temperatures with needle thermocouples passed vertically into the region (Whyte and Reader, 1951).

(a) Short-Wave Infra-Red Radiation.-This was supplied from a 1,000-watt tungsten filament lamp;* it was applied to a $12 \times 12 \mathrm{~cm}$. area in the maximum intensity which could be tolerated without being uncomfortable. The intensity was 2.5 pyrons (g. cal./ sq. $\mathrm{cm}$./min.), measured with the thermoradiometer of Evans and Mendelssohn (1946). Heating was continued for $18 \mathrm{~min}$., by which time equilibrium was established in the region.

(b) Long-Wave Infra-Red Radiation.-This was supplied from an 800-watt Sollux dark-source element; ${ }^{*}$ it was applied to the same area, giving the same sensation (1.5 pyrons intensity), until equilibrium was produced.

(c) Contact Heat.-This was applied to an area of $200 \mathrm{sq}$. cm. with a rubberbottomed metal container (Reader, 1951) through which hot water was passed. Heat was applied for $46 \mathrm{~min}$.; all tissue temperatures were steady for the last $28 \mathrm{~min}$.; the sensation was of comfortable warmth. A narrow vertical channel through the centre of the container allowed of deep temperatures being recorded.

(d) Ultra-Short-Wave Diathermy.-This was supplied from an "Ultratherm" apparatus operating at a fixed wave-length of $6 \mathrm{~m}$. and a frequency of 50 megacycles. Soft rubber condenser electrodes $(18 \times 12 \mathrm{~cm}$.) were placed one over $2 \mathrm{~cm}$. of felt on the right side of the abdomen and one over $1 \mathrm{~cm}$. of felt on the right lumbar region. Heating was continued for $30 \mathrm{~min}$. at the full output of 23 filament volts. The local sensation was of mild warmth. Skin temperature and deep temperatures were recorded

* We are indebted to Hanovia Ltd., Slough, for lending this lamp. 
before heating and again within $1 \mathrm{~min}$. after the heat was switched off. Thermocouples were not present during heating.

\section{Results}

The results are illustrated in the Figure. The lumbar region normally has a skin temperature of $33-34^{\circ} \mathrm{C}$., while subcutaneous temperatures vary with depth, rising to a maximum of about $37 \cdot 3^{\circ} \mathrm{C}$. at a depth of $3 \mathrm{~cm}$., beyond which they are constant. This deep temperature is probably the temperature of blood flowing into the region. When contact heat or radiant heat is applied temperatures rise highest on the skin and fall with increasing depth until the normal level is reached at 3 or $4 \mathrm{~cm}$.

Short-wave infra-red produced the highest skin temperature, $44.5^{\circ} \mathrm{C}$., and raised the subcutaneous temperatures more effectively than either long-wave infra-red or contact heat.

By far the most effective heating of muscle was given by the Ultratherm apparatus. The maximum temperature recorded was $40.9^{\circ} \mathrm{C}$. at a depth of $15 \mathrm{~mm}$., and temperatures were found to exceed $39^{\circ} \mathrm{C}$. over the whole depth of 5 to $40 \mathrm{~mm}$. Deep temperatures exceeded superficial temperatures. These were recorded, the more superficial ones first, within $1 \mathrm{~min}$. of stopping the heating, and although the temperatures would fall in that time, the change is believed to have been small. In a large number of experiments in which the temperature changes following radiant heating were measured, the temperature at a depth of $5 \mathrm{~mm}$. never fell more than $0.5^{\circ} \mathrm{C}$. in the first minute.

\section{Discussion}

Several points of interest arise from these results. The first is that the effectiveness of heating is practically the same with a contact method as with radiant heat from a dark source. Both of these methods are most useful for heating skin and, although tissues to a depth of 3 or $4 \mathrm{~cm}$ : are warmed, the methods are of little value for raising deep temperatures much above the temperature of blood. The results in the present study are not strictly comparable, since different degrees of heat were used, but it is unlikely that the effectiveness of the methods differ to any extent, as in both cases the heat is absorbed at the surface and then spreads inwards by conduction and convection. The same considerations will apply to all forms of localized heating applied to the surface, such as hot-water bottles, hot-water, wax and other substances, and electric pads or blankets.

The second point is the superiority of the tungsten-lamp radiation over radiant heat of longer wave-lengths. This is largely attributable to the ability of short-wave infra-red radiation to penetrate skin. The maximum output of the tungsten filament lamp is in the region of the wave-length $1 \mu$, which is the most penetrating part of the spectrum of radiant heat (Hardy and Muschenheim, 1934, 1936). The results also show that both surface and deep temperatures can be maintained at a higher level with the same degree of comfort when the tungsten lamp rather than the dark-source radiation is used. This has been confirmed 


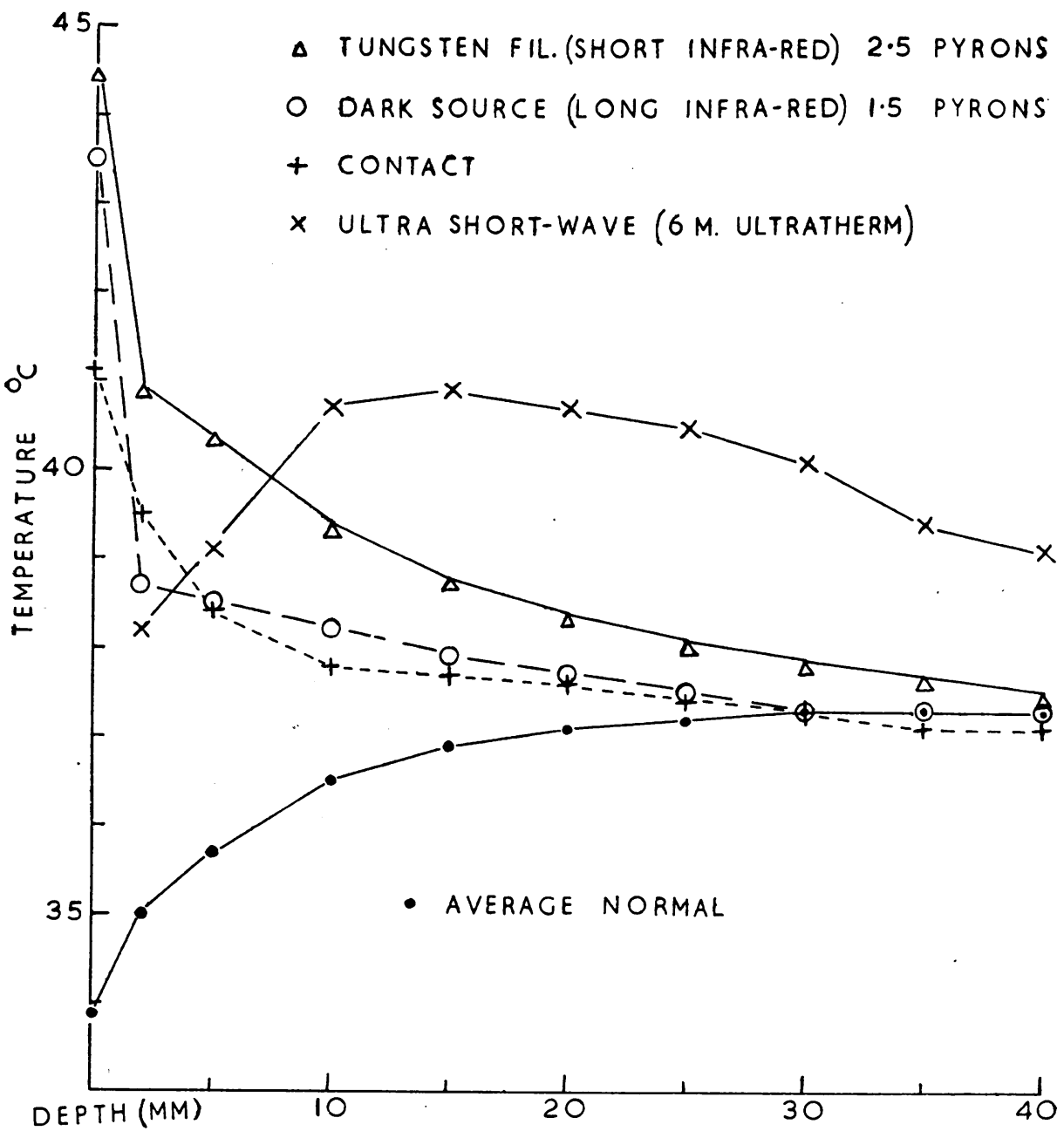

FIGURE. Temperatures produced in the lumbar region by different methods of heating.

for a large series of observations in different subjects. The difference in intensities of the two lamps is largely due to reflection by skin of a considerable proportion of the tungsten radiation.

The third point is the usefulness of diathermy for heating muscle. Grunspan (1913) showed that diathermy was superior to hot air blown on the surface, and recorded muscle temperatures of $40 \cdot 5^{\circ} \mathrm{C}$. after $15 \mathrm{~min}$. heating. Mittelmann and others (1941) found that deep temperatures could be raised to $41^{\circ} \mathrm{C}$. without discomfort and without much surface heating.

Finally, needle thermocouples, as used in the present investigation, can be recommended for recording deep temperatures and measuring the changes caused by different procedures such as the application of heat or cold. The lumbar region has many advantages for a study of this type. 


\section{Summary}

Surface and deep temperature changes produced by different methods of heating in the lumbar region have been recorded.

The skin was best heated with radiation from a tungsten filament lamp and the muscle with ultra-short-wave diathermy.

The short-wave infra-red radiation from the bright tungsten lamp heated skin and deep tissues better than the long-wave infra-red radiation from a dark source.

The changes produced by the dark source of radiation and contact heat were similar.

\section{REFERENCES}

Evans, D. S., and Mendelssohn, K. (1946). J. sci. Instrum., 23, 94.

Grunspan, M. (1913). Rev. Chir., Paris, 48, 585.

Hardy, J. D., and Muschenheim, C. (1934). J. clin. Invest., 13, 817.

- _ (1936). Ibid., 15, 1.

Mittelmann, E., Osborne, S. L., and Coulter, J. S. (1941). Arch. phys. Ther., 22; 133.

Reader, S. R. (1952). Clin. Sci., 11, pt. 1, (in the press).

Whyte, H. M. (1951). Ibid. 10, 325.

-, and Reader, S. R. (1951). J. appl. Physiol., 4, (in the press).

\section{Efficacité de différentes méthodes d'application de la chaleur}

\section{RÉSUMÉ}

On enregistra les variations de la température superficielle et profonde produites dans la région lombaire par différentes méthodes de chauffage.

Le meilleur échauffement de la peau fut obtenu au moyen de l'irradiation par une lampe au filament de tungstène, tandis que celui des muscles fut obtenu par la diathermie à ondes ultracourtes.

Les rayons infra-rouges à ondes courtes provenant d'une lampe lumineuse au tungstène chauffèrent la peau et les tissus profonds mieux que les rayons infra-rouges à grandes ondes émanant d'une source obscure.

Les altérations produites par les rayons d'une source obscure et par la chaleur de contact furent similaires.

\section{Eficacia de varios métodos de aplicación del calor}

\section{SUMARIO}

Fueron enregistradas variaciones en la temperatura sụperficial y profunda producidas en la región lumbar por diferentes métodos de calentamiento.

El mejor calentamiento de la piel fué obtenido mediante la irradiación procedente de una lámpara con filamento de tungsteno y el de los músculos por diatermia de onda ultracorta.

Los rayos infrarrojos de onda corta producidos por una lámpara luminosa a filamento de tungsteno calentaban la piel y los tejidos profundos mejor que los rayos infrarrojos de onda larga emanados de una fuente obscura.

Las alteraciones producidas por una fuente obscura de rayos y por el calor de contacto fueron similares. 